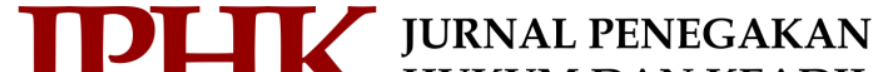 HUKUM DAN KEADILAN}

Vol. 2 No.1, Maret 2021, Hal.72-95

P-ISSN: 2746-0967, E-ISSN: 2721-656X
Gedung Pascasarjana Kampus Terpadu UMY Jalan Brawijaya, Tamantirto, Kasihan, Bantul, Yogyakarta 55183

Telepon : (0274) 387656 Ext. 346

Email : jphk@umy.ac.id

\title{
Reformulasi Pengaturan Sistem Kerja Pegawai Pemerintah Kota Yogyakarta Pada Masa Adaptasi Kebiasaan Baru
}

Allan Fatchan Gani Wardhana*, Yuniar Riza Hakiki

Fakultas Hukum, Universitas Islam Indonesia

*) Corresponding Email: allanfowardhana@uii.ac.id

\section{INFO ARTIKEL}

Perjalanan Artikel:

Artikel Dikirimkan oleh penulis: 21-12-20

Artikel Direview: 09-03-21

Artikel Direvisi: 28-04-21

Artikel Diterima atau

Dipublikasikan: 03-05-21

DOI:

https://doi.org/10.18196/jphk .$v 2 i 1.10651$

\begin{abstract}
ABSTRAK
Pandemi Covid 19 berdampak pada sistem dan manajemen kerja birokrasi. Ada perubahan kultur bekerja birokrasi dengan model WFH dan WFO. Sistem manajemen kinerja ASN selama pelaksanaan WFH dinilai belum efektif karena sistem kontrol yang belum terpusat bahkan sebagian sumber daya instansi dinilai belum siap menerapkan sistem WFH, tidak terkecuali di lingkungan Pemerintah Kota Yogyakarta. Kondisi saat ini, tatanan kebiasaan baru yang sedang diterapkan di lingkungan pemerintah telah memaksa seluruh lini untuk beradaptasi. Penelitian ini bertujuan menganalisis kondisi pengaturan dan menggagas reformulasi pengaturan sistem kerja birokrasi di Pemerintah Kota Yogyakarta pada masa adaptasi kebiasaan baru. Dengan metode penelitian yuridis normatif yang menggunakan data sekunder dari hasil studi kepustakaan (library research) dan didukung olahan informasi dari hasil survei dan Focus Group Discussion (FGD), penelitian ini menyimpulkan bahwa pengaturan sistem kerja melalui Peraturan Walikota Kota Yogyakarta Nomor 54 Tahun 2020 tentang Pedoman Tata Kerja Pegawai dalam Tatanan Normal Baru di Pemerintah Kota Yogyakarta mengadopsi 2 (dua) sistem kerja (model blended system), yaitu Work From Office (WFO) sebagai sistem kerja yang dilaksanakan di kantor dan Work From Home (WFH), sehingga guna meraih peluang dalam momentum reformasi birokrasi di masa pandemi, maka penelitian ini memformulasikan kerangka alternatif desain pengaturan sistem kerja WFO yang dikolaborasi dengan WFH sebagai satu kesatuan sistem kerja di Pemerintahan Kota Yogyakarta, yang meliputi penataan metode kerja, penataan jadwal kerja, penataan akses data/dokumen kerja, serta metode pemantauan/pengawasan dan evaluasi kinerja.
\end{abstract}

Kata Kunci: Reformulasi, Pengaturan, Pegawai, Pemerintah Kota Yogyakarta

\section{Pendahuluan}

Peraturan Presiden Nomor 81 Tahun 2010 tentang Grand Design Reformasi Birokrasi Nasional menjadi acuan penting dalam menapaki jalan mewujudkan birokrasi yang oleh Eddy Cahyono disebut birokrasi yang baik dan bersih (good and 
clean bureaucracy). ${ }^{1}$ Reformasi Birokrasi diharapkan dapat mendorong terwujudnya pelayanan publik yang sesuai dengan harapan masyarakat, harapan bangsa Indonesia yang semakin maju dan mampu bersaing dalam dinamika global yang semakin ketat, kapasitas dan akuntabilitas kinerja birokrasi semakin baik, SDM aparatur semakin profesional, dan mind-set serta cultureset yang mencerminkan integritas dan kinerja semakin tinggi. ${ }^{2}$ Sehingga, pada tahun 2025, telah terwujud tata pemerintahan yang baik dengan birokrasi pemerintah yang profesional, berintegritas tinggi, dan menjadi pelayan masyarakat dan abdi negara. ${ }^{3}$

Rentang waktu 6 (enam) tahun dari 2019 menuju 2025 untuk mewujudkan tata pemerintahan yang baik kemudian menemui tantangan serius yaitu kondisi dimana sistem kerja birokrasi dan pelayanan publik dihadapkan pada pandemi global Corona Virus Disease 2019 (Covid 19) yang kemudian memaksa pola kerja Aparatur Sipil Negara (ASN) harus menyesuaikan dan cepat beradaptasi. Persebaran Covid 19 yang begitu cepat membuat Pemerintah mengeluarkan berbagai langkah antisipasi dan adaptasi, terutama dalam hal sistem kerja birokrasi di bidang pelayanan publik. Dalam konteks ini, antisipasi dan adaptasi yang dilakukan salah satunya dengan mengeluarkan kebijakan hukum.

Tercatat ada dua keputusan penting di bidang hukum yang kemudian menyebabkan aktivitas birokrasi dan pelayanan publik menjadi terbatas. Keputusan Presiden Nomor 11 Tahun 2020 tentang Penetapan Kedaruratan Kesehatan Masyarakat Covid 19 yang dikeluarkan pada tanggal 31 Maret 2020. Substansi Keppres tersebut menetapkan bahwa Covid 19 merupakan jenis penyakit yang menimbulkan kedaruratan kesehatan masyarakat sehingga wajib dilakukan upaya penanggulangan sesuai dengan ketentuan perundang-undangan. ${ }^{4}$ Kemudian disusul dengan Keputusan Presiden Nomor 12 Tahun 2020 tentang Penetapan Bencana Non Alam Penyebaran Covid 19 sebagai Bencana Nasional yang keluar tanggal 13 April 2020. Substansi Keppres 12/2020 menetapkan bahwa Covid 19 merupakan bencana non alam dan bencana nasional. ${ }^{5}$ Berdasarkan dua keputusan di atas, Covid 19 dianggap menjadi bencana nasional non alam yang menimbulkan kedaruratan kesehatan masyarakat

1 Cahyono, E. (2020). Asisten Deputi Hubungan Masyarakat Kementerian Sekretaris Negara, The New

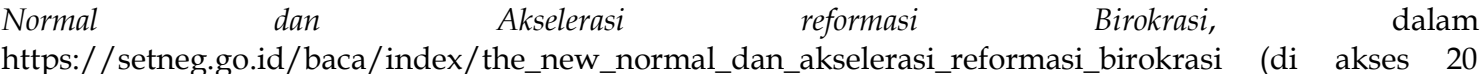
Oktober 2020)

2 Penjelasan Peraturan Presiden Republik Indonesia Nomor 81 Tahun 2010 tentang Grand Design Reformasi Birokrasi Nasional.

${ }^{3}$ Ibid.

4 Konsideran Keputusan Presiden Nomor 11 Tahun 2020 berbunyi "bahwa penyebaran Corona Virus Disease 2019 (COVID-19) yang bersifat luar biasa dengan ditandai jumlah kasus dan/atau jumlah kematian telah meningkat dan meluas lintas wilayah dan lintas negara yang berdampak pada aspek politik, ekonomi, sosial, budaya, pertahanan dan keamanan, serta kesejahteraan masyarakat di Indonesia". 5 Konsideran Keputusan Presiden Nomor 12 Tahun 2020 berbunyi "bahwa bencana nonalam yang disebabkan oleh penyebaran Corona Virus Disease 2019 (COVID-19 )telah berdampak meningkatnya jumlah korban dan kerugian harta benda, meluasnya cakupan wilayah yang terkena bencana, serta menimbulkan implikasi pada aspek sosial ekonomi yang luas di Indonesia; bahwa World Health Organization (WHO) telah menyatakan COVID-19 sebagai Global Pandemic tanggal 11 Maret 2020." 
sehingga perlu dilakukan langkah-langkah pencegahan dan penindakan untuk mengatasi pandemi.

Dua keputusan tersebut, menjadi dasar penetapan berbagai regulasi/kebijakan baik yang dikeluarkan pemerintah pusat dalam bentuk Peraturan Pemerintah/Peraturan Menteri/Surat Edaran Menteri, maupun Pemerintah Daerah dalam bentuk Peraturan Daerah/Peraturan Kepala Daerah/Surat Edaran Kepala Daerah. Kelahiran berbagai regulasi/kebijakan dalam kacamata sosiologi hukum adalah sarana untuk merekayasa perubahan sekaligus kontrol sosial. Hal ini senada dengan yang dikatakan oleh Roscoe Pound bahwa law is a tool of social engineering and law is a tool of social control. Bahkan menurut Pound, a process of social engineering as a part of the whole process of social control. ${ }^{6}$

Penyesuaian sistem kerja dan pelayanan publik selama masa pandemi di Pemerintah Kota Yogyakarta diawali dengan dasar regulasi/kebijakan berupa Surat Edaran Gubernur Daerah Istimewa Yogyakarta (DIY) Nomor 800/5316 tentang Penyesuaian Sistem Kerja Pegawai Dalam Status Tanggap Darurat Bencana Covid 19 di wilayah DIY. Kemudian diikuti dengan Surat Edaran Walikota Yogyakarta Nomor 061/978/SE/2020 tentang Penyesuaian Sistem Kerja Pegawai Dalam Status Tanggap Darurat Bencana Covid 19 di Pemerintah Kota Yogyakarta.

Penetapan regulasi dari Gubernur DIY dan Walikota Yogyakarta tidak terlepas dari penyebaran Pandemi Virus COVID-19 secara cepat di Kota Yogyakarta membuat ASN menjalankan tugas pekerjaan dan pelayanan dari rumah atau Work from Home atau WFH untuk menghindari penyebaran virus tersebut lebih lanjut. Pelaksanaan WFH bagi ASN di lingkungan Pemerintah Kota Yogyakarta berlangsung semenjak penetapan SE Walikota Nomor 061/978/SE/2020 yang ditetapkan pada bulan Maret 2020. Kemudian pada 1 Juli 2020, Walikota menerbitkan Peraturan Walikota Yogyakarta Nomor 54 Tahun 2020 tentang Pedoman Tata Kerja Pegawai dalam Tatanan Normal Baru di Pemerintah Kota Yogyakarta yang pada pokoknya mengolaborasi sistem kerja WFH dan Work from Office (WFO).

Penerapan WFH dihadapkan dengan berbagai permasalahan yang belum pernah dihadapi dan terbayangkan sebelumnya. Pertama, belum adanya Standar Operasional dan Prosedur (SOP) baku yang ditetapkan secara nasional berkaitan dengan pelaksanaan WFH. Kemenpan RB memberikan kebebasan bagi setiap instansi untuk mengatur pelaksanaan WFH di setiap instansi. Namun kebebasan implementasi memicu perbedaaan penerjemahan instruksi seperti mekanisme sistem pencatatan kehadiran atau presensi ASN. Persoalan tersebut tidak sederhana, sebab presensi kehadiran mempengaruhi tunjangan kinerja serta penilaian kinerja bagi para ASN.

Kedua, pelaksanaan WFH menyebabkan kesulitan bagi ASN dalam mengakses data dari rumah. Data yang dimiliki oleh instansi pemerintahan telah terintegrasi dalam bentuk soft file sehingga pada saat dibutuhkan, ASN tetap harus datang ke

${ }^{6}$ Gardner, James A. (1961). The Sociological Jurisprudence of Roscoe Pound (Part I), Villanova Law Review, 7(1), hal. 16. 
kantor untuk mengambil dokumen fisik. Ketiga, pemberlakukan WFH berpengaruh signifikan terhadap kualitas pelayanan publik yang menghajatkan pertemuan langsung seperti pelayanan administrasi kependudukan. Disisi lain, Pemerintah Kota Yogyakarta terpacu untuk membuat inovasi penyelenggara pelayanan administrasi melalui sistem dalam jaringan (online) dan paperless sehingga dapat menghindari interaksi tanpa mengurangi kualitas pelayanan yang dibutuhan masyarakat.

Keempat, Pandemi Covid-19 telah mengubah paradigma bekerja ASN menjadi lebih efektif dan efisien, lebih berorientasi pada hasil dari pada procedural. Kondisi WFH menjadi salah satu akselerator terhadap penerapan Sistem Pemerintahan Berbasis Elektronik (SPBE) sehingga menjadi kebutuhan semua birokrat, sebagai akibat kebijakan work from home. ${ }^{7}$ Kendala penerapan SPBE adalah adanya kebutuhan kapasitas dan fasilitas teknologi yang mumpuni sehingga dapat menunjang kinerja. Fakta lapangan menunjukan Pemerintah Kota Yogyakarta masih terkendala dari kapasitas sumber daya manusia maupun fasilitas dalam mengakses sarana dan prasarana teknologi yang compatible dengan mekanisme SPBE.

Kelima, potensi terbatasnya kemampuan dan kapasitas pelayanan publik dalam memenuhi standar pelayanan. Pasal 21 Undang-undang Nomor 25 Tahun 2009 tentang Pelayanan Publik mengamanatkan bahwa penyelenggara pelayanan publik mempunyai kewajiban untuk memenuhi komponen standar pelayanan minimal seperti persyaratan, dasar hukum, sistem mekanisme prosedur, jangka waktu penyelesaian, biaya, produk layanan, dan lain-lain. Keberadaan kebijakan pembatasan pelayanan publik dalam bentuk tatap muka, seharusnya tidak mengurangi kepatuhan birokrasi dalam memberikan pelayanan prima dan efekif. Sehingga hak dan kewajiban masing-masing pihak baik penyelenggara maupun masyarakat tetap berjalan sesuai ketentuan Pasal 14 sampai dengan Pasal 19 UU Pelayanan Publik.

Keenam, secara tidak langsung keberadaan WFH menjadi stimulan bagi ASN untuk bekerja lebih fleksibel dari sisi waktu maupun tempat bekerja. Prinsip dan konsep fleksibilitas bekerja tersebut telah banyak diadopsi perusahaan swasta maupun BUMN jauh sebelum pandemi, namun belum diterapkan pada lingkungan birokrasi. Konsep fleksibilitas menuntut pekerja termasuk ASN dapat bekerja tanpa ada batasan waktu bekerja, sepanjang target pekerjaan dapat terpenuhi tepat waktu. Konsep WFH ini, jika tidak dipandu dan dibiasakan justru berpotensi menurunkan motivasi kerja dan meningkatkan kelelahan disebabkan mereka belum terbiasa untuk mengelola pekerjaan secara mandiri tanpa pengawasan.

Sistem kerja ASN selama pelaksanaan WFH masih belum efektif disebabkan sistem kontrol yang belum terpusat bahkan sebagian sumber daya instansi dinilai belum siap menerapkan sistem WFH. Sistem kerja WFH yang berlangsung selama pandemi dapat dikatakan sebagai momentum dan kesempatan untuk melakukan uji coba sehingga satu saat nanti dapat diberlakukan jangka panjang.

\footnotetext{
7 Natalisa, Diah. Deputi bidang Pelayanan Publik Kementerian PANRB, Tatanan Normal Baru Butuh Birokrasi Pelayanan yang Sederhana, dalam https://www.menpan.go.id/site/berita-terkini/tatanannormal-baru-butuh-birokrasi-pelayanan-yang-sederhana (diakses 20 Oktober 2020)
} 
Tatanan Kebiasaan Baru yang sedang diterapkan telah memaksa seluruh lini beradaptasi. Pemerintah melalui Kementerian Pendayagunaan Aparatur Negara dan Reformasi Birokrasi (PANRB) menyiapkan strategi untuk untuk mewujudkan pelayanan publik di masa adaptasi kebiasaan baru dengan optimal. Penyederhanaan birokrasi menjadi kunci transformasi pelayanan publik selama Covid-19 masih mewabah. Menurut Deputi bidang Pelayanan Publik Kementerian PANRB, Diah Natalisa, momentum tatanan normal baru merupakan sebuah kesempatan untuk melakukan akselerasi dalam mewujudkan transformasi pelayanan. ${ }^{8}$

Penerapan sistem WFH secara permanen dapat berjalan efektif manakala memenuhi beberapa persyaratan. Diantaranya adalah keberadaan payung hukum yang jelas dan deskriptif, sistem WFH terpusat se-Indonesia terutama dalam hal monitoring, adanya SOP yang jelas setiap instansi, dan mudah diterima masyarakat serta tidak mengganggu kerja pelayanan publik. Adaptasi kebiasaan baru adalah hal yang tidak dapat dielakkan, sehingga pola kerja ASN yang tetap menjaga bahkan meningkatkan kualitas pelayanan publik harus dapat disesuaikan kembali. Kajian terhadap pengaturan sistem kerja di Pemerintahan Kota Yogyakarta pada tatanan normal baru sangat penting untuk ditelaah untuk kemudian dapat disesuaikan dengan tetap berorientasi pada pelayanan publik yang optimal.

Kajian tentang birokrasi di masa pandemi ini sebagian telah dilakukan secara bervariatif oleh beberapa peneliti. Anin Dhita dan Riris Katharina menganalisis tantangan yang dihadapi oleh birokrasi di masa pandemi Covid-19, sekaligus mendorong ditetapkannya kriteria kebijakan dan indikator keberhasilan kinerja birokrasi di masa pandemi. ${ }^{9}$ Taufik dan Hardi Warsono menganalisis perubahan birokrasi di era new normal melalui pendekatan model perubahan organisasi, sekaligus mengusulkan penguatan kapasitas ASN dalam menguasai aplikasi berbasis digital, edukasi kepada masyarakat terhadap pelayanan manual ke online, dan pengembangan infrastruktur berbasis digital. ${ }^{10}$ Selanjutnya, ada juga yang meneliti kebijakan Pemerintah Provinsi Jawa Tengah dalam mendukung kinerja ASN di masa pandemi Covid-19. Erni Irawati berkesimpulan bahwa Pemerintah, dalam hal ini aparat birokrasi dituntut untuk mampu beradaptasi dan merespon perubahan tersebut agar mampu memfasilitasi kesejahteraan dan pembangunan yang berkelanjutan.11

Berdasarkan uraian di atas, tergambar bahwa isu sistem kerja birokrasi di masa pandemi ini memiliki porsi yang penting mendapat perhatian untuk terus menerus dikaji. Urgensi kajian tersebut ditengarai kebutuhan untuk terus mengevaluasi

\footnotetext{
${ }^{8} \underline{\text { Ibid. }}$.

9 Amrynudin, A.D.K. dan Katharina, R. (2020). Birokrasi dan Kebijakan Percepatan Penanganan Covid-19", Info Singkat Pusat Penelitian Badan Keahlian DPR RI, 12(9), 25-30.

${ }^{10}$ Taufik dan Warsono, H. 2020. Birokrasi Baru untuk New Normal: Tinjauan Model Perubahan Birokrasi dalam Pelayanan Publik di Era Covid-19. Dialogue Jurnal Ilmu Administrasi Publik. 2(1), 1-18.

${ }^{11}$ Irawati, E. (2020). Aparatur Sipil Negara di Masa Pandemi: Tinjauan Kebijakan Normal Baru di Provinsi Jawa Tengah. Prosiding The $2^{\text {nd }}$ Seminar on Population, Family and Human Resources, hal. 99-105.
} 
kebijakan sistem kerja pada birokrasi di masa pandemi, sekaligus perumusan konsep perbaikannya. Penelitian ini fokus mengkaji pengaturan sistem kerja pegawai, dengan objek kajiannya adalah Peraturan Walikota Yogyakarta Nomor 54 Tahun 2020 tentang Pedoman Tata Kerja Pegawai dalam Tatanan Normal Baru di Pemerintah Kota Yogyakarta yang merupakan dasar hukum bagi kebijakan Pemerintah Kota Yogyakarta dalam mengatur sistem kerja aparaturnya.

\section{Metodologi}

Metode yang digunakan dalam penelitian ini ialah metode penelitian yuridis normatif dengan menggunakan data sekunder yang diperoleh dari hasil studi kepustakaan (library research) dan didukung olahan informasi dari hasil survei dan Focus Group Discussion (FGD). Bahan penelitian ini menggunakan bahan hukum primer, sekunder, dan tersier. Bahan hukum primer yang paling utama digunakan adalah Peraturan Walikota Yogyakarta Nomor 54 Tahun 2020 tentang Pedoman Tata Kerja Pegawai dalam Tatanan Normal Baru di Pemerintah Kota Yogyakarta. Metode analisis yang digunakan dalam penelitian ini ialah analisis deskriptif-kualitatif dengan metode pendekatan peraturan perundang-undangan (statute approach) dan pendekatan konsep (conceptual approach).

\section{Analisis dan Hasil}

3.1. Pengaturan Sistem Kerja Pegawai di Pemerintah Kota Yogyakarta dalam Masa Adaptasi Kebiasaan Baru

Penyelenggaraan pemerintahan di Indonesia dihadapkan pada suatu realitas bahwa badan dan/atau pejabat tata usaha negara bertugas memberikan pelayanan publik berdasarkan tata hukum/peraturan perundang-undangan. Tugas pemerintah ini bermula dari konsekuensi ajaran negara kesejahteraan (welfare state) yang menghendaki negara dan pemerintah terlibat aktif dalam kehidupan ekonomi dan sosial masyarkat, sebagai langkah untuk mewujudkan kesejahteraan umum, di samping menjaga ketertiban dan keamanan (rust en orde). ${ }^{12}$

Sejak perkembangan Covid 19 di nasional dan di Kota Yogyakarta mengalami tren kenaikan, Kementerian Pendayagunaan Aparatur Negara dan Reformasi Birokrasi (KemenpanRB) mengeluarkan berbagai Surat Edaran kepada ASN dalam rangka penyesuaian kerja. Begitupun ketika Pemerintah menggunakan istilah tatanan normal baru, KemenpanRB juga mengeluarkan Surat Edaran tata kerja pegawai dalam tatanan normal baru. Pemerintah Kota Yogyakarta kemudian juga menyesuaikan dengan mengeluarkan Peraturan Walikota Yogyakarta Nomor 54 Tahun 2020 tentang Pedoman Tata Kerja Pegawai dalam Tatanan Normal Baru di Pemerintah Kota Yogyakarta.

12 Ridwan. (2020). Hukum Administrasi Negara, Depok: Rajawali Pers, hal. 14. 
Kebijakan yang dipilih oleh Pemerintah Kota Yogyakarta melalui Peraturan Walikota Yogyakarta Nomor 54 Tahun 2020 tentang Pedoman Tata Kerja Pegawai dalam Tatanan Normal Baru di Pemerintah Kota Yogyakarta adalah menerapkan pola kerja work from office dan work from home. Pasal 1 angka (4) dan Pasal 1 angka (3) Perwal Nomor 54 Tahun 2020 tentang Pedoman Tata Kerja Pegawai dalam Tatanan Normal Baru di Pemerintah Kota Yogyakarta menentukan definisi Work from Office (WFO) yaitu sistem kerja yang dilaksanakan di kantor sedangkan Work from Home (WFH), yaitu sistem kerja dari rumah pada hari tertentu atau untuk periode sementara guna meminimalisir risiko pada kesehatan dan keselamatan pegawai. Artinya sistem kerja pegawai di Pemerintah Kota Yogyakarta menggunakan model blended system. Hanya saja sistem kerja WFH ini didefinisikan hanya untuk periode sementara guna meminimalisir risiko pada kesehatan dan keselamatan pegawai. Hal itu menunjukkan bahwa pemberlakuan sistem kerja WFH ini tidak didesain untuk jangka panjang, melainkan hanya sementara saja.

Perihal penggunaan sistem kerja WFH yang hanya untuk sementara ini perlu memperoleh pencermatan. Sistem kerja WFH yang hanya diberlakukan sementara ini cenderung tidak disertai desain yang mapan dan komprehensif. Hal ini dibuktikan dari belum diaturnya metode/tata kerja, jadwal kerja, sistem komunikasi kerja, sistem koordinasi data/dokumen kedinasan, mekanisme pemantauan/pengawasan, serta evaluasi untuk sistem kerja WFH di dalam Perwal Nomor 54 Tahun 2020. Perwal Nomor 54 Tahun 2020 baru sebatas mengatur kriteria pegawai yang dapat bekerja dari rumah, pembimbingan/pendampingan oleh atasan, serta pelaporan kinerja melalui EKinerja saja. Sedangkan, tata kerja secara lebih rincinya belum diatur lebih lanjut, baik pengaturan secara umum maupun secara rinci.

Penetapan Perwal No 54/2020 menjadikan SE Walikota No 061/5493/SE/2020 dicabut dan dinyatakan tidak berlaku. Perwal No 54/2020 dikeluarkan dengan pertimbangan kebijakan penanganan paparan Covid-19 tidak boleh mengabaikan keberlangsungan pelayanan publik. Sehingga protokol kesehatan menjadi faktor yang harus dijaga sebagai upaya pencegahan dan pengendalian di lingkungan perkantoran Pemerintah Kota Yogyakarta.

Perwal No 54/2020 mengatur tata kerja dalam tatanan normal baru dengan rangkuman materi muatan sebagai berikut:

1. Pencegahan dan pengendalian Covid-19 pada semua situasi baik mencakup kondisi sumber daya manusia, lingkungan maupun ruang kerja, baik untuk kebutuhan pelayanan internal maupun pelayanan public

2. Seluruh ASN di Pemerintah Kota Yogyakarta melaksanakan tugas kedinasan di kantor WFO, diperbolehkan WFH dengan persyaratan tertentu. Prosedur protokol kesehatan selama WFO yang harus ditaati oleh ASN diatur ${ }^{13}$ sebagai berikut:

${ }^{13}$ Lampiran Peraturan Walikota Yogyakarta Nomor 54 Tahun 2020 tentang Pedoman Tata Kerja Pegawai Dalam Tatanan Normal Baru Di Pemerintah Kota Yogyakarta. 
a. pengecekan suhu rutin dan menggunakan masker semenjak dr rumah dan selama bekerja di kantor

b. Jika suhu badan $\geq 37,5^{\circ} \mathrm{C}$ atau mengalami gejala gangguan sistem pernapasan dilarang masuk. ASN wajib mengkomunikasikan kepada layanan kesehatan terdekat.

3. Pelaksanaan masuk kerja diatur sebagai berikut:

a. Jam kerja berlaku dengan 5 (lima) hari kerja atau 6 (enam) hari kerja

b. Presensi kerja baik WFH atau WFO menggunakan aplikasi online

c. ASN dapat bekerja WFH dengan syarat: status ODP/PDP, kontral erat dengan pasien konfirmasi covid-19, riwayat perjalanan dari luar daerah dengan zona merah/luar negeri, ASN hami bereski tinggi (comorbid)

d. Mekanisme bekerja WFH karena status kesehatan sebagai ODP/PDP maupun dinyatakan kontak erat dengan pasien terkomfirmasi covid-19 adalah sebagai berikut :

(1) Dinyatakan ODP/PDP dengan bukti Surat Keterangan Puskesmas/RS

(2) Melaporkan tertulis kepada Kepala Perangkat Daerah/Unit Kerja dengan melampirkan Surat Keterangan

(3) Kepala Perangkat Daerah/Unit Kerja mengajukan usulan isolasi mandiri selama 14 (empat belas) hari kepada Walikota

(4) Sekretaris Daerah atas nama Walikota menetapkan Surat Perintah Isolasi Mandiri

(5) Isolasi mandiri dapat diperpanjang jika PDP belum sembuh, hingga dinyatakan sehat oleh Puskesmas/Rumah Sakit.

(6) Pimpianan langsung memberikan bimbingan/pendampingan dalam penyelesaian tugas dan bertindak sebagai verifikator.

(7) Akuntabilitas kinerja ASN dilaksanakan melalui aplikasi E-Kinerja dan dibawah tanggungjawab verifikator.

4. Mekanisme ASN yang bekerja WFH disebabkan hamil dengan comorbid, sama dengan ASN sebagai PDP/ODP. Perbedannya terletak pada Surat Keterangan yang dibuat Dokter Spesialis dari Rumah Sakit

5. Kegiatan yang bersifat mengumpulkan peserta dalam jumlah banyak seperti rapat/pertemuan atau apel/upacara/senam pagi/kegiatan dilaksanakan secara selektif, menjalankan protokol kesehatan dan mengutamakan teknologi informasi dan komunikasi atau melalui media elektronik lainnya

6. Pengaturan sistem kerja BUMD diserahkan sepenuhnya kepada Direktur BUMD.

Adapun terhadap Perwal Nomor 54 Tahun 2020 terdapat catatan sebagai berikut: Pertama, Peraturan Walikota ini muncul sebagai upaya untuk memutus mata rantai penularan Corona Virus Disease 2019 (COVID-19). Adapun berbagai kebijakan penanganan Corona Virus Disease 2019 (COVID-19) harus tetap mendukung keberlangsungan pelayanan publik oleh Pemerintah Kota Yogyakarta, sehingga dari aspek kesehatan perlu dilakukan upaya pencegahan dan pengendalian pada tempat 
kerja perkantoran di Pemerintah Kota Yogyakarta; Kedua, Peraturan Walikota ini merupakan pedoman tata kerja bagi Pegawai dalam mencegah dan mengendalikan penyebaran Corona Virus Disease-19 (Covid-19) di Pemerintah Kota Yogyakarta. Artinya sejak awal didesain sebagai instrumen sekaligus pedoman tata kerja pegawai dalam melayani publik.

Ketiga, ruang lingkup pedoman tata kerja bagi Pegawai di Pemerintah Kota Yogyakarta dalam mencegah dan mengendalikan penyebaran Corona Virus Disease-19 (Covid-19) meliputi: a) pra kondisi sumber daya manusia, lingkungan, dan ruang kerja; b) pelaksanaan kerja; c) pelayanan internal; dan d. pelayanan eksternal (publik). Akan tetapi substansi Peraturan Walikota harus dikaji ulang karena materi muatannya lebih cocok apabila menjadi materi muatan SOP yang dapat dibentuk oleh Kepala Organisasi Perangkat Daerah. Seharusnya dalam level Peraturan Walikota diatur mengenai penataan metode kerja, penataan jadwal kerja, penataan akses data/dokumen kerja, serta metode pemantauan/pengawasan dan evaluasi kinerja.

Peraturan Walikota mestinya diarahkan untuk mengatur manajemen tata kerja pegawai, sementara hal-hal yang berkaitan dengan hal-hal teknis seperti pra kondisi sumber daya manusia, pra kondisi lingkungan kerja, pelaksanaan kerja yang lebih banyak berisi uraian teknis, serta protokol pelayanan internal dan eksternal kantor lebih baik diturunkan pada level SOP di masing-masing OPD. Ini selaras dengan konsep materi muatan peraturan perundang-undangan bahwa yang mengatur tata kehidupan masyarakat yang jauh lebih mendasar;, ${ }^{14}$ dan Keempat, Peraturan Walikota ini menjadi dasar hukum kepada seluruh Pegawai di Pemerintah Kota Yogyakarta untuk melaksanakan tugas kedinasan di kantor (work from office) dan tugas kedinasan dari rumah (work from home) dengan tetap memperhatikan protokol kesehatan. Akan tetapi Peraturan Walikota ini belum mengatur pola kerja pegawai dalam dua model tugas kedinasan secara rinci terutama model pembagian tugas dan tolok ukur capaian pelaksanaan tugas.

Terhadap pemberlakuan sistem kerja WFH bagi pegawai di lingkungan Pemerintah Kota Yogyakarta mengindikasikan kecenderungan bahwa sistem kerja WFH hanya diadopsi untuk kebutuhan dalam kondisi pandemi Covid-19 saja. Padahal sistem kerja WFH merupakan salah satu sistem kerja yang telah lama diterapkan di berbagai organisasi dan berpotensi menjadi budaya kerja baru bagi birokrasi pemerintahan, karena corak fleksibilitasnya yang tidak mengesampingkan produktivitas. Riset yang dilakukan Oswar Mungkasa, ${ }^{15}$ mengurai bahwa bekerja secara jarak jauh (WFH) pada dasarnya dapat memberikan banyak manfaat bagi pekerja maupun organisasi, diantaranya adalah keseimbangan kehidupan bekerja dan

\footnotetext{
14 Attamimi, H.. (2018). Perbedaan antara Peraturan Perundang-undangan dan Peraturan Kebijaksanaan, Suatu Tantangan Bagi Peran POLRI Dewasa ini dan Menghadapi Pembangunan Jangka Panjang Kedua, sebagaimana dikutip kembali oleh SF Marbun. (2018). Hukum Administrasi Negara 1, Yogyakarta: FH UII Press, hal. 256257

15 Mungkasa, O. (2020). Bekerja dari Rumah (Working from Home/WFH): Menuju Tatanan Baru Era Pandemi COVID 19. The Indonesian Journal of Development Planning, 4(2), hal. 131.
} 
keluarga, mengurangi waktu perjalanan ke kantor sekaligus menghemat bahan bakar, mengendalikan jadwal kerja maupun menjaga suasana kerja termasuk dapat memilih bekerja ketika suasana hati sedang baik. Sementara manfaat bagi organisasi adalah memiliki pekerja yang semangat bekerja, mengurangi angka kegagalan dan ketidakhadiran, mengurangi pergantian pekerja serta memperkuat citra perusahaan sebagai tempat bekerja yang ramah keluarga.

Hanya saja, bila sistem kerja WFH ini tidak disertai dengan pengaturan yang rinci dan komprehensif memang memunculkan berbagai kendala dan masalah. Informasi yang penulis temukan dalam penerapan sistem kerja WFH berdasarkan hasil survei dan focus group discussion (FGD) pihak ketiga, bahwa terhadap sejumlah Aparatur Sipil Negara (ASN) di lingkungan Pemerintah Kota Yogyakarta secara umum menunjukkan sistem ini sulit diimplementasikan karena terkendala berbagai hal. ${ }^{16}$ Kendala tersebut diantaranya, kesulitan mengakses data/dokumen kedinasan, kesulitan berkomunikasi dengan rekan kerja, kesulitan menggunakan media \& teknologi, ketiadaan dukungan teknologi yang memadai, kesulitan untuk melakukan pengukuran kinerja. Secara umum, kendala tersebut lantaran disebabkan belum mapannya pengaturan mengenai desain sistem kerja WFH.17

Disamping itu, sistem kerja konvensional melalui kantor atau tren saat ini disebut dengan Work from Office (WFO) masih menjadi sistem kerja yang terus dipertahankan, bahkan telah menjadi keharusan dan kewajiban. Meski ditengah kondisi yang masih pandemi, Pemerintah Kota Yogyakarta tetap menerapkan WFO dengan standar protokol kesehatan. WFO memang tidak dapat dipungkiri sebagai sebuah sistem kerja birokrasi yang paling dirasakan dan dinilai efektif, karena pengerjaan dan koordinasi kerjanya dapat dilakukan secara langsung. Pembinaan, pemantauan, pengawasan dan evaluasi kinerja pun dapat secara langsung dilakukan. Selain itu, sistem kerja WFO ini juga diperlukan untuk jenis pekerjaan pelayanan publik yang bersinggungan langsung dengan masyarakat.

Hanya saja, sistem kerja WFO dalam kondisi pandemi virus sangat rentan menimbulkan dampak penyebaran/penularan virus. Pun bila ditinjau dari segi efisiensi, justru berpotensi kurang efisien karena memerlukan alokasi waktu khusus, biaya akomodasi, ruang kerja, mobilisasi pegawai yang berdampak pada beban penumpukan massa di kantor maupun di jalan raya (transportasi). Padahal kondisi Pandemi Covid-19 telah mengubah paradigma sistem bekerja ASN menjadi lebih efektif dan efisien. Pemerintah Kota Yogyakarta harus memanfaatkan situasi ini untuk mengoptimalkan pelayanan publik dengan tetap memprioritaskan kesehatan dan keselamatan pegawai di lingkungan Pemerintah Kota Yogyakarta.

16 Olahan informasi dari hasil survei dan Focus Group Discussion (FGD) yang difasilitasi Anagata Sasmitaloka Consulting (ANSAC) Yogyakarta pada tanggal 11 Agustus 2020 dalam Laporan Penelitian ANSAC, Yogyakarta, 2020.

17 Ibid. 


\subsection{Reformulasi Pengaturan Sistem Kerja Pegawai Pemerintah Kota Yogyakarta dalam Masa Adaptasi Kebiasaan Baru}

Pembahasan mengenai sistem kerja birokrasi tidak bisa dipisahkan dari agenda reformasi birokrasi yang telah ditentukan dalam Grand Design Reformasi Birokrasi 2010 - 2025. Adapun reformasi birokrasi berkaitan dengan ribuan proses tumpang tindih (overlapping) antar fungsi-fungsi pemerintahan, melibatkan jutaan pegawai, dan memerlukan anggaran yang tidak sedikit. Selain itu, reformasi birokrasi pun perlu menata ulang proses birokrasi dari tingkat (level) tertinggi hingga terendah dan melakukan terobosan baru (innovation breakthrough) dengan langkah-langkah bertahap, konkret, realistis, sungguh-sungguh, berfikir di luar kebiasaan/rutinitas yang ada (out of the box thinking), perubahan paradigma (a new paradigm shift), dan dengan upaya luar biasa (business not as usual).18

Reformasi birokrasi perlu memodernkan berbagai kebijakan dan praktik manajemen pemerintah pusat dan daerah, dan menyesuaikan tugas fungsi instansi pemerintah dengan paradigma dan peran baru, seperti misalnya ketika dihadapkan pada pandemi Covid-19. Sistem kerja birokrasi yang dihadapkan pada pandemi ini harus disesuaikan dengan cara merumuskan strategi pelaksanaan transformasi penyelenggaraan pemerintahan termasuk pelayanan publik. Prinsip-prinsip dalam tujuan reformasi birokrasi harus mendasari pelaksanaan penyesuaian sistem kerja birokrasi pada masa pandemi. Birokrasi publik dituntut harus mampu memberikan pelayanan yang sebaik mungkin, baik kepada publik maupun kepada investor, maka salah satu strategi untuk merespon perkembangan global tersebut adalah dengan meningkatkan kapasitas birokrasi dalam pemberian pelayanan publik. ${ }^{19}$

Berdasakan hal di atas, maka sistem kerja birokrasi di Pemerintah Kota Yogyakarta sendiri juga harus menyesuaikan dengan paradigma dan kebiasaan baru. Namun penyesuaian ini harus tetap dalam kerangka reformasi birokrasi yang ke depan pada tahun 2025 diharapkan telah terwujud tata pemerintahan yang baik dengan birokrasi pemerintah yang profesional, berintegritas tinggi, dan menjadi pelayan masyarakat dan abdi Negara. Di tengah pandemi Covid 19, Pemerintah Kota Yogyakarta harus terus melakukan tugas untuk menciptakan birokrasi yang profesional dengan karakteristik adaptif, berintegritas, berkinerja tinggi, bersih dan bebas korupsi, kolusi dan nepotisme, mampu melayani publik, netral, sejahtera, berdedikasi, dan memegang teguh nilai-nilai dasar dan kode etik aparatur negara. salah satu cara untuk menciptakan birokrasi sebagaimana tersebut di atas dilakukan melalui manajemen kepegawaian.

Perlu ada strategi untuk melakukan manajemen kepegawaian. Secara konsep terdapat 3 (tiga) keahlian yang mendasar dalam manajemen kepegawaian, yaitu keahlian teknis, keahlian personal, dan keahlian konseptual. Pertama, keahlian teknis

18 Penjelasan Peraturan Presiden Republik Indonesia Nomor 81 Tahun 2010 tentang Grand Design Reformasi Birokrasi Nasional.

19 Yuningsih, T. (2019). Kajian Birokrasi. Semarang: Departemen Administrasi Publik Press FISIP-UDIP, hal. 100 
(technical skill) meliputi kemampuan untuk menerapkan pengetahuan atau keahlian khusus. Kedua, keahlian personal kemampuan untuk bekerja sama, memahami, dan memotivasi orang lain, baik secara individual maupun dalam kelompok. Ketiga, keahlian konseptual yaitu kemampuan mental untuk menganalisis dan mendiagnosis situasi-situasi.20 Pemerintah Kota Yogyakarta dalam melakukan manajemen kepegawaian ini perlu mengambil pelajaran dari pandemi Covid-19. Terdapat lima hal yang dapat dipelajari dari pandemi Covid-19:21

1. perubahan perilaku dan budaya. Melalui penerapan work from home (WFH) dan work from office (WFO), pegawai tidak perlu hadir di kantor secara fisik (cukup hadir secara virtual), tetapi dapat terhubung melalui pemanfaatan Teknologi, Informasi, dan Komunikasi.

2. reformasi pelayanan, dimana pelayanan tatap muka bertransformasi menjadi layanan online. Hal ini mendorong penyederhanaan proses bisnis dan SOP yang berujung pada kemudahan proses perizinan dan bukan perizinan.

3. penghematan anggaran belanja pemerintah. Masa pandemi ini memaksa pemerintah untuk berpikir kreatif dan melakukan efisiensi anggaran dari berbagai sumber tanpa harus mengurangi produktivitas.

4. sinergitas dan kolaborasi. Melalui penanganan Covid-19 dapat disimpulkan bahwa usaha memerangi pandemi Covid-19 dibutuhkan kolaborasi dan sinergi antara seluruh komponen masyarakat, pemerintah, maupun swasta.

5. inovasi dan terobosan baru menjadi sebuah kebutuhan.

Terkait dengan pemanfaatan informasi teknologi di atas, faktanya telah terjadi perubahan secara masif budaya kerja dan cara berpikir Aparatur Sipil Negara (ASN) yaitu percepatan dalam pemanfaatan teknologi informasi dan komunikasi dalam praktik tata kelola pemerintahan, yang lebih berorientasi pada hasil dengan mengedepankan pemanfaatan informasi teknologi dan kecepatannya. Kondisi Pandemi Covid-19 telah mengubah paradigma bekerja ASN menjadi lebih efektif dan efisien, lebih berorientasi pada hasil daripada prosedural. Percepatan penerapan Sistem Pemerintahan Berbasis Elektronik (SPBE) telah menjadi kebutuhan pada semua level birokrasi, sebagai konsekuensi masifnya praktik bekerja dari rumah atau work from home. Instansi pemerintah sekarang sudah umum melakukan tele-meeting atau teleconference dan pengadaan rapat-rapat koordinasi yang menggunakan teknologi digital tanpa dibatasi ruang dan waktu dan lokasi sehingga lebih efektif efisien dari sisi waktu dan biaya. ${ }^{22}$

Melihat situasi ini, Pemerintah Kota Yogyakarta harus mereformulasi sistem kerja baru melalui adaptasi kebiasaan baru. Terdapat lima komponen utama perubahan ruang kerja baru birokrasi menurut Prasojo yaitu:23

20 Sawir, M. (2020). Tinjauan Mengenai Fungsi Birokrasi Pemerintahan Di Indonesia, dalam https://core.ac.uk/download/pdf/229023096.pdf , hlm. 214 (diakses 21 September 2020)

${ }^{21}$ Natalisa, D., Op. Cit.

22 Cahyono, E. Op. Cit.

23 Taufik dan Warsono, H. Op. Cit., hal. 11-12. 
1. Ruang kerja yang fleksibel dan berjejaring.

2. Penyiapan infrastruktur dan pembelajaran super application (superapp) yang memungkinkan kantor virtual dan digital. Perubahan ruang kerja baru yang semula dilakukan di gedung perkantoran, kini menjadi berkurang kebutuhannya di era new normal.

3. Peningkatan kapabilitas ASN dalam berinteraksi dengan berbagai kemajuan teknologi informasi dan komunikasi termasuk dengan big data dan artificial intelligent sangat dibutuhkan.

4. Dalam era new normal pasca Covid 19 harus segera dilakukan penataan bisnis proses dan alur kerja birokrasi. Adanya penyederhanaan prosedur pelayanan dengan memanfaatkan pelayanan berbasis digitalisasi sehingga pelayanan kepada masyarakat dapat dilakukan dengan mudah dan cepat.

5. Era new normal birokrasi membutuhkan pegawai ASN yang berkualitas dan berkompetensi untuk mengelola ruang kerja baru. Pegawai ASN yang dibutuhkan adalah yang berkompetensi, tidak berdasarkan pada kuantitas, namun kualitas yang mampu melakukan berbagai pekerjaan secara cepat dan berkualitas.

Pemerintah Kota Yogyakarta perlu untuk segera mendesain sistem kerja WFO yang dikolaborasi dengan WFH sebagai satu kesatuan sistem kerja di Pemerintahan Kota Yogyakarta. Kerangka sistem kerja WFO dan WFH ini meliputi penataan metode kerja, penataan jadwal kerja, penataan akses data/dokumen kerja, serta metode pemantauan/pengawasan dan evaluasi kinerja. Adapun penjelasannya adalah sebagai berikut:

\section{Metode Kerja}

Metode kerja yang dimaksud disini berarti 'tata cara' yang diatur untuk melaksanakan sistem kerja WFH dan WFO. Pemerintah Kota perlu mengatur tata cara bekerja bagi ASN yang WFH dengan ASN yang melaksanakan WFO. Metode kerja ini sekurang-kurangnya meliputi standar metode kerja, penentuan jenis pekerjaan yang disertai dengan alternatif cara dan pedoman pengerjaannya, penentuan jenis pekerjaan yang dikerjakan secara individu atau kelompok, prosedur dan media komunikasi kerja antar sesama pegawai. Beberapa hal tersebut merupakan kerangka model pengaturan metode kerja yang tentunya dapat disesuaikan pada masing-masing organisasi perangkat daerah yang menerapkan sistem kerja WFO yang dikolaborasi dengan WFH ini.

\section{Penataan Jadwal Kerja.}

Pemerintah Kota Yogyakarta perlu mengatur penataan jadwal kerja melalui WFH, sekurang-kurangnya meliputi penentuan standar waktu kerja minimal, mengkategorisasian alternatif durasi waktu kerja dengan berpedoman pada waktu kerja birokrasi, penentuan jenis pekerjaan yang dikaitkan dengan durasi pengerjaan. Guna mengolaborasi sistem kerja WFO dan WFH, pemerintah kota dapat mengatur 
fleksibilitas waktu bekerja. Sebagai ilustrasi, pemerintah kota dapat menerapkan waktu kerja ASN minimal selama 1 minggu adalah 20 jam, dengan disertai alternatif waktu koordinasi virtual pada pukul 08.00 - 10.00, 10.00 - 12.00, 13.00 - 15.00. Atau dapat pula disertai penetapan hari tertentu (Senin dan Kamis misalnya) untuk berkoordinasi langsung di kantor (WFO).

\section{Penataan Akses dan Penyimpanan Data atau Dokumen Kerja}

Pemerintah kota perlu mendesain jaringan akses dan penyimpanan data atau dokumen kerja kedinasan, serta berangsur-angsur mulai menata dokumentasi data atau dokumen secara paperless. Sejumlah aplikasi pihak ketiga dapat dimanfaatkan untuk menunjang hal ini atau sistem aplikasi yang dirancang mandiri oleh pemerintah kota. Pegawai secara bersama-sama mengakses satu ruang aplikasi, sehingga bisa saling bertukar data atau dokumen kerja kedinasan secara virtual.

4. Metode Pemantauan/Pengawasan dan Evaluasi Kinerja.

Kontrol atau pegawasan adalah fungsi di dalam manajemen fungsional yang harus memeroleh bimbingan. ${ }^{24}$ Kendala dan kesulitan mengukur kinerja \& produktivitas pegawai tentu dapat diatasi dengan metode pemantauan atau pengawasan dan evaluasi kinerja virtual yang tepat. Pada prinsipnya, metode pemantauan atau pengawasan dan evaluasi kinerja tetap dilakukan berdasarkan peraturan perundang-undangan, terutama Undang-Undang Nomor 5 Tahun 2014 tentang Aparatur Sipil Negara, Peraturan Pemerintah Nomor 30 Tahun 2019 tentang Penilaian Kinerja Pegawai Negeri Sipil, Peraturan Menteri Pendayagunaan Aparatur Negara dan Reformasi Birokrasi Nomor 38 Tahun 2018 tentang Pengukuran Indeks Profesionalitas Aparatur Sipil Negara, serta Peraturan Walikota Kota Yogyakarta Nomor 78 Tahun 2019 tentang Penilaian Kinerja Pegawai.

Guna mewujudkan sistem kerja kolaboratif di Pemerintah Kota Yogyakarta, yakni dengan sistem kerja WFO dengan WFH maka perlu didukung beberapa sub sistem manajemen. Sub sistem manajemen ini antara lain manajemen sumber daya pegawai, manajemen jenis pekerjaan, manajemen konektivitas antara sistem kerja WFH dan WFO, manajemen infrastruktur pendukung sistem kerja, serta manajemen dukungan anggaran.

1. Manajemen Sumber Daya Pegawai.

Manajemen sumber daya manusia adalah mengelola sumber daya manusia. Dari keseluruhan sumberdaya yang tersedia dalam organisasi (pemerintah), sumber daya manusia lah yang sangat penting dan sangat menentukan. Semua potensi yang dimiliki sumber daya manusia sangat berpengaruh kepada upaya organisasi dalam mencapai tujuan. Oleh karena itum manajemen sumber daya manusia mempunyai tiga

24 M. Kadarisman. (2013). Manajemen Pengembangan Sumber Daya Manusia. Jakarta:Rajawali Press, hal. 172. 
fungsi yaitu fungsi manajerial, fungsi operasional, dan berfungsi mencapai tujuan organisasi secara terpadu. ${ }^{25}$

Manajemen sumber daya pegawai berkaitan dengan penataan dan pemetaan penempatan kerja (meliputi lokasi kerja dan jabatan). Pemerintah kota memetakan lokasi kerja dan jabatan untuk menempatkan pegawai yang harus melakukan kerja secara WFO serta pegawai yang dapat melakukan kerja secara WFH. Selain itu juga disertai penataan jenis pekerjaan dan cara kerjanya. Hal ini memerhatikan jenis-jenis dan kualifikasi pekerjaan yang bisa dilakukan secara WFH dan pekerjaan yang harus dilakukan secara WFO. Pelatihan dan pembinaan kinerja dilakukan baik untuk sistem kerja WFO maupun WFH. Pelatihan dan pembinaan kinerja yang mesti mendapat perhatian, khususnya untuk pegawai yang menjalankan pekerjaan dengan sistem WFH.

Manajemen sumber daya pegawai memerhatikan kompetensi atau kemampuan pegawai, kondisi kesehatan pegawai, kondisi zonasi risiko pandemi di Kota Yogyakarta. Kompetensi atau kemampuan pegawai dapat ditentukan berdasarkan penilaian kinerja yang berkait dengan pelatihan dan pembinaan. Ukuran penentuan kondisi kesehatan pegawai telah diatur dalam pedoman tata kerja pegawai dalam tatanan normal baru (Perwal Nomor 54 Tahun 2020). Sedangkan penentuan lokasi kerja pegawai yang memerhatikan kondisi zonasi risiko pandemi dapat merujuk Surat Edaran Menteri PANRB Nomor 67 Tahun 2020 tentang Perubahan atas Surat Edaran Menteri PANRB Nomor 58 Tahun 2020 tentang Sistem Kerja Pegawai ASN dalam Tatanan Normal Baru.

\section{Manajemen Jenis Pekerjaan}

Guna memanajemen sumber daya pegawai untuk melakukan pekerjaan secara WFO dan WFH, maka perlu ada pemilahan dan pengkategorisasian jenis pekerjaan. Pemerintah memetakan jenis pekerjaan kedinasan yang dapat dikerjakan dengan sistem WFH dan jenis pekerjaan kedinasan yang mengharuskan dikerjakan dengan sistem WFO.

Pemetaan sekurang-kurangnya dapat berpedoman pada 3 (tiga) klaster: (a) pekerjaan kedinasan yang berhadapan langsung dengan masyarakat yang memerlukan kehadiran langsung pegawai; (b) pekerjaan kedinasan yang tidak berhadapan langsung dengan masyarakat tetapi harus dihadiri langsung (fisik) oleh pegawai; (c) pekerjaan kedinasan yang tidak harus dihadiri langsung oleh pegawai, dan berbagai klaster (indikator kategorisasi) lain sesuai jenis-jenis pekerjaan kedinasan di lingkungan Pemerintah Kota Yogyakarta.

\section{Manajemen Konektivitas antara Sistem Kerja WFH dan WFO}

Sebagai satu kesatuan sistem kerja birokrasi masa adaptasi kebiasaan baru, sistem kerja melalui WFH dan WFO itu tidak bisa berjalan sendiri-sendiri. Keduanya

${ }^{25}$ Husaini, Abdullah. (2017). Peranan Manajemen Sumber Daya Manusia dalam Organisasi. Jurnal Warta (50). 
harus didesain saling terkait melalui sebuah sistem atau media kerja digital. Masa adaptasi kebiasaan baru menjadi momentum penerapan e-Government secara optimal dan menyeluruh. Pemerintah Kota Yogyakarta dapat mencontoh model kerja dan pelayanan yang diselenggarakan oleh perusahaan-perusahaan swasta. Mereka mengolaborasi sistem online dan offline, baik untuk manajemen kinerja pegawainya maupun untuk manajemen pelayanan.

Hanya saja, konektivitas sistem kerja secara WFH (online) dengan WFO (offline) memang harus didukung sistem aplikasi digital yang memadai. Pegawai dilatih menggunakan sistem aplikasi tersebut dalam mengerjakan pekerjaan yang dibebankan kepadanya. Seluruh pegawai terhubung dalam satu kesatuan sistem aplikasi, sehingga dapat saling berkomunikasi secara virtual dan dapat saling mengakses maupun menyimpan data atau dokumen kedinasan.

Pemerintah Kota Yogyakarta juga dapat mendesain sistem pelayanan administrasi yang sebisa mungkin menihilkan pertemuan antara masyarakat dengan pemerintah (pegawai). Sistem pelayanan publik secara elektronik yang selama ini diselenggarakan perlu ditingkatkan dan diperluas penerapannya untuk berbagai jenis pelayanan publik.

\section{Manajemen Infrastruktur Pendukung Sistem Kerja}

Pemerintah Kota Yogyakarta perlu membangun dan mengembangkan infrastruktur pendukung sistem kerja WFO yang dikolaborasikan dengan sistem kerja WFH. Terutama sistem teknologi atau komunikasi, transformasi peralatan kerja dari peralatan konvensional menuju peralatan berbasis teknologi digital, transformasi desain ruang atau lokasi kerja yang mendukung optimalnya penerapan protokol kesehatan. Selain itu, juga perlu peningkatan kapasitas dan kemampuan pegawai dalam menjalankan sistem IT. Sebab, persoalan kapasitas dan kemampuan pegawai dalam mengoperasikan pekerjaan dengan sistem IT masih menjadi kendala dalam pelayanan publik. Sebagaimana hasil penelitian Hernita Sahban, dkk menunjukkan bahwa penguasaan perangkat keras dan perangkat lunak sistem IT memiliki pengaruh besar terhadap pelayanan birokrasi. ${ }^{26}$

\section{Manajemen Dukungan Anggaran}

Guna mewujudkan sistem kerja yang kolaboratif ini, tentu berdampak pada keuangan daerah, terutama mengenai perubahan alokasi anggaran dari yang semula anggaran berbasis pada sistem kerja konvensional, berubah menjadi anggaran berbasis sistem kerja berbasis teknologi digital. Pemerintah Kota Yogyakarta perlu mengalokasikan anggaran untuk membangun dan mengembangkan sistem yang berbasis teknologi atau aplikasi digital. Selain itu, alokasi anggaran pada sistem konvensional yang dapat dipangkas dapat dialihkan pada pengembangan sistem kerja berbasis digital. Sebagai contoh, dalam sistem kerja konvensional memerlukan

\footnotetext{
26 Sahban, H.. (2018). Meningkatkan Kinerja Pelayanan Birokrasi Pemerintahan Melalui Penguasaan Teknologi Informasi. Jurnal Manajemen Bisnis, 5(2), 57-65.
} 
anggaran untuk akomodasi pegawai, sedangkan apabila pemerintah kota mulai bertansformasi pada sistem kerja berbasis digital, maka anggaran akomodasi pegawai dapat dialihkan untuk alokasi kuota atau jaringan internet.

Di Indonesia, Flexible Working Arrangement sebenarnya bukanlah hal yang baru karena telah ada beberapa organisasi di sektor bisnis yang telah menerapkan sistem tersebut dengan tujuan menarik pegawai dan menekan tingkat turn over pekerja. Sebagai contoh: Bank BTPN, Telkom, Astra International dan lain-lain. Sedangkan di sektor publik, penerapan FWA masih didominasi penyesuaian atau pengaturan flexy untuk mengkompensasi keterlambatan pegawai (flexible working hours) dan bukan dalam bentuk formal pengelolaan kinerja. Mungkin di beberapa intansi pemerintah (misalnya inisiasi BPK untuk Jabatan Fungsional Auditor) sudah menerapkan model ini, namun secara formal dalam bentuk kebijakan Manajemen ASN secara spesifik belum ada.

Sebelum adanya instruksi bagi pekerja, khususnya ASN untuk melakukan Work From Home, wacana ASN bekerja di rumah sebenarnya sudah muncul pada pertengahan bulan Agustus tahun 2019 seperti yang disampaikan oleh Menteri PANRB Syafruddin setelah melihat perkembangan teknologi saat ini. Dengan memanfaatkan teknologi, siapa pun bisa bekerja di mana saja, kapan saja. Namun, wacana ini juga masih ada pro dan kontra terkait kesiapan baik pegawainya sendiri dan juga saran dan prasarana saat bekerja di rumah. Dengan pandemi COVID-19 yang sudah cukup menyebar di Indonesia, wacana yang mulanya hanya di implementasikan di salah satu instansi dan untuk beberapa pegawai saja (sebelumnya rencana ASN bisa bekerja dari rumah akan diuji coba pertama kali di Kementerian Perencanaan Pembangunan Nasional (PPN)/Bappenas), siap ataupun tidak harus dilakukan untuk mencegah penyebaran virus tersebut.

Kondisi Pandemi Corona 19 yang dialami sejak bulan Mei 2020 di Indonesia mengakibatkan ada penyesuaian manajemen kinerja ASN untuk menjalankan pekerjaan dengan sistem Flexible Working Arrangement atau Work From Home. Begitu juga yang telah dilaksanakan oleh ASN Pemerintah Kota Yogyakarta sejak bulan Mei 2020 sebagian ASN bekerja dari rumah atau dengan istilah Working From Home dan sebagian lagi tetap melaksanakan pekerjaan di kantor atau Working From Office. Birokrasi memang harus mampu dan mau melakukan transformasi diri dari birokrasi yang kinerjanya kaku (rigid) menjadi organisasi birokrasi yang strukturnya lebih desentralistis, inovatif, fleksibel, dan responsif. ${ }^{27}$

Surat Edaran Menteri PANRB Nomer 34 tahun 2020 tentang tentang Perubahan Surat Edaran Menteri PAN-RB Nomor 19 Tahun 2020 tentang Penyesuaian Sistem Kerja Aparatur Sipil Negara dalam Upaya Pencegahan Penyebaran Covid-19 di Lingkungan Instansi Pemerintah terdapat beberapa ketentuan yang berkaitan ketentuan penyelenggaran Work From Home. Pertama, penyesuaian sistem kerja Aparatur Sipil Negara di Instansi Pemerintah dapat bekerja di rumah atau tempat

27 Fadillah, P. (2009). Senjakala Good Governance. Malang: Averroes Press. 
tinggal (Work from Home), namun Pejabat Pembina Kepegawaian (PPK) memastikan minimal terdapat 2 level Pejabat Struktural tertinggi tetap melaksanakan tugasnya di kantor agar penyelenggaraan pemerintahan dan pelayanan kepada masyarakat tidak terganggu.

Pejabat Pembina Kepegawaian Kementerian, Lembaga atau Daerah agar mengatur sistem kerja yang akuntabel dan selektif dalam mengatur pejabat/pegawai di lingkungan unit kerjanya yang dapat bekerja dari rumah atau tempat tinggal (Work from Home) melalui pembagian kehadiran dengan mempertimbangkan: jenis pekerjaan, peta sebaran Covid-19 resmi dari Pemerintah, domisili pegawai, kondisi kesehatan pegawai, kondisi kesehatan keluarga pegawai (dalam status "pemantauan", "diduga", "dalam pengawasan", atau "dikonfirmasi" terjangkit Covid-19), riwayat perjalanan luar negeri pegawai dalam 14 hari terakhir, riwayat interaksi pegawai dengan penderita Covid-19 dalam 14 hari terakhir, serta efektivitas pelaksanaan tugas dan pelayanan unit organisasi.

Kedua, penyelenggaraan kegiatan dan perjalanan dinas. Kegiatan tatap muka yang menghadirkan banyak peserta agar ditunda atau dibatalkan, penyelenggaraan rapat dilakukan secara selektif sesuai prioritas dan urgensi dengan memanfaatkan Teknologi Informasi (TI) dan media elektronik yang tersedia, apabila harus diselenggarakan rapat tatap muka karena urgensi yang sangat tinggi, maka perlu memperhatikan jarak aman antar peserta rapat (social distancing).

Berdasarkan hasil survei yang dilakukan ANSAC selama bulan Juli - Agutstus 2020,28 terhadap 464 responden ASN Pemerintah Kota Yogyakarta diperoleh informasi bahwa 53,7 \% menyatakan bahwa tugas dan pekerjaan ASN Pemerintah Kota Yogyakarta yang dilakukan sehari-hari di kantor dapat dilakukan dengan waktu yang flexible atau bekerja dari rumah, sedangkan 46,3\% menyatakan tidak dapat dilakukan dengan waktu yang flexible atau bekerja dari rumah. Dari 53,7\% yang menyatakan bisa bekerja Work From Home atau Flexible Working Arrangement dengan alasan pekerjaannya berkaitan administratif dan adanya dukungan teknologi informasi dalam melaksanakan pekerjaannya terutama berkaitan dokumen ataupun data. Sedangkan dari $46,3 \%$ yang menyatakan tidak bisa melaksanakan pekerjaanya secara flexible ataupun bekerja dari rumah dengan alasan pekerjaannya berkaitan dengan pelayanan kesehatan, pekerjaan lapangan, dan aktifitas pekerjaannya harus melakukan pencermatan secara langsung karena mengalami kesulitan dilaksanakan secara online seperti melihat data lapangan ataupun berkaitan dengan verifikasi dokumen.

Mengutip ketentun dari Surat Edaran Surat Edaran Menteri PANRB Nomer 34 tahun 2020, bahwa Pejabat Pembina Kepegawaian Kementerian, Lembaga, atau Daerah agar mengatur sistem kerja yang akuntabel dan selektif dalam mengatur pejabat atau pegawai di lingkungan unit kerjanya yang dapat bekerja dari rumah atau tempat tinggal (Work from Home) melalui pembagian kehadiran dengan

28 Hasil olahan Survei ANSAC Yogyakarta pada bulan Juli - Agustus 2020 dalam Laporan Penelitian ANSAC, 2020. 
mempertimbangkan jenis pekerjaan. Namun, implementasi secara rincinya mengenai kelayakan pekerjaan ASN yang dapat dilakukan di rumah ataupun ketentuan prosedural mengenai bagaimana mengatur bekerja dari rumah perlu diatur pada ketentuan yang ada pada Pemerintah Kota Yogyakarta.

Pemerintah Kota Yogyakarta perlu menentukan posisi yang layak untuk bekerja jarak jauh, dan secara jelas ditetapkan dalam kebijakan. Melalui analisis model jenis pekerjaan dan operasional kantor, pemerintah kota dapat menetapkan skema bekerja jarak jauh seluruh kantor yang mencakup jenis pekerjaan, posisi, bahkan pengaturan waktu yang tepat untuk bekerja jarak jauh (termasuk kemungkinan skema bergiliran). Walaupun kemudian dapat terjadi tidak ada satupun pekerjaan yang dapat dilaksanakan di luar kantor. Namun sepanjang ditetapkan dengan jelas dalam kebijakan maka hal ini tidak akan menjadi sumber pertanyaan di masa depan.

Namun dalam kondisi pandemi Covid-19 ketika sekolah ditutup, atapun kelompok belajar untuk anak balita juga ditutup dan kemudian ASN kembali lagi diarahkan untuk bekerja dari kantor, terdapat kondisi pegawai tidak dapat melakukannya berdasar kondisi atau alasan tertentu atau menyebabkan ada aktivitas yang perlu dilakukan secara flexible. Sebagai ilustrasi, ketika ASN disaat giliran masuk ke kantor tetapi kemudian sekolah masih diliburkan dan membuat orang tua tidak dapat bekerja di kantor karena untuk menjaga sang anak.

Kebijakan pemerintah kota perlu dinyatakan secara jelas bentuk pengaturannya termasuk jadwal, pengaturan kehadiran di kantor jika tidak bekerja di luar kantor, dukungan instansi atau menyiapkan perlengkapannya sendiri di rumah. Pengaturan jadwal perlu disepakati sejak awal untuk menghindari kecemburuan dan perasaan diperlakukan tidak adil dari pegawai yang tetap bekerja di kantor atau sedang dapat giliran bekerja di kantor. Selain itu, perlu dipikirkan kompensasi bagi pegawai yang tidak mempunyai peluang bekerja di luar kantor.

Keberadaan pegawai yang jauh dari pengamatan langsung pimpinan kadang memunculkan rasa kecurigaan atau kekhawatiran bahwa pegawai tidak melaksanakan tugasnya sesuai aturan. Untuk itu, kecepatan pegawai dalam menanggapi pertanyaan atau permintaan dari kantor maupun sesama pegawai akan membantu menghilangkan kekhawatiran tersebut. Pengaturan kecepatan tanggapan tersebut secara tertulis, maupun bentuk perangkat komunikasi yang dipergunakan menjadi bagian penting dalam kebijakan. Penetapan kebijakan yang jelas dapat menghindari terjadinya hubungan yang kurang harmonis diantara atasan dengan pegawai dan sesama pegawai.

Salah satu faktor yang mendorong maraknya bekerja jarak jauh adalah hasil penelitian yang menunjukkan peningkatan produktivitas bekerja jarak jauh lebih baik dari bekerja konvensional. Namun keberadaan pegawai yang jauh dari pantauan langsung pimpinan membutuhkan pemilihan metode baru pengukuran produktivitas pegawai. Terdapat banyak pilihan metode pengukuran mulai dari lamanya waktu pelaksanaan pekerjaan, jumlah masalah yang terselesaikan, sampai jumlah rekanan 
yang tertangani. Tentu saja metode pengukuran tidak sesederhana sekedar menghitung jumlah lamanya bekerja, tetapi lebih berfokus pada keluaran (output) yang dihasilkan.

Walaupun demikian, pemantauan lamanya bekerja dan penyerahan laporan perkembangan pekerjaan tetap diperlukan. Dan berkaitan hal ini ASN Pemerintah Kota Yogyakarta sudah menerapkan metode pemantuan kinerja yang disebut dengan aplikasi e-kinerja. Namun, yang perlu dipertimbangkan untuk berfokus pada keluaran yang dihasilkan bahkan hingga kualitas hasil kerjanya sebagai ukuran kegiatan selama menjalankan tugasnya walaupun ASN bekerja tidak berada dari kantor atau dilakukan secara Flexible Working Arrangement atau Working From Home, bukan sekedar berdasarkan jumlah jam kerja atau waktu aktifitasnya yang diukur sebagai acuan kinerjanya.

Presensi daring termasuk lokasinya dilakukan awal dan akhir dilengkapi dengan laporan harian. Beberapa perusahaan swasta telah dilengkapi dengan aplikasi yang dapat mengakomodasi presensi, pelaporan, diskusi daring, berbagi informasi dan lainnya. Pemantauan terhadap kemajuan pekerjaan dapat dilakukan secara daring dan berkala. Hal ini juga sebagai pengganti pertemuan tatap muka diantara pegawai yang sering terjadi di kantor.

Kehadiran pegawai secara fisik bersifat fleksibel dan dapat dibantu teknologi canggih saat ini. Teknologi digunakan untuk memastikan keberadaan pegawai dan penyelesaian target pekerjaan, misalnya, meskipun pegawai berada di rumah, organisasi dapat melakukan kontrol atas jam kerja dan pelaksanaan pekerjaan. Beberapa contoh penggunaan teknologi seperti komputer dengan login kehadiran pegawai, email sebagai media transfer hasil pekerjaan, fixed dan mobile phone, teleconference, skype dan teknologi lainnya sebagai media komunikasi, koordinasi dan kontrol dalam pelaksanaan pekerjaan secara nyata memberikan kontribusi keberhasilan Flexible Working Arrangement atau Working From Home. Teknologi digunakan untuk menjamin 'kehadiran' jam kerja dan pencapaian kinerja pegawai sesuai yang diharapkan. Dan ASN Pemerintah Kota Yogyakarta sudah cukup didukung dengan adanya aplikasi e-kinerja dan e-office sebagai pemantau kehadiran bekerja jarak jauh.

Bekerja jauh dari kantor membutuhkan perangkat pendukung mulai dari komputer jinjing (laptop) atau komputer meja, telepon genggam, printer, dan lainnya. Keseluruhan perangkat tersebut perlu ditetapkan dalam kebijakan instansi terkait penanggungjawab penyediaannya. Bisa saja perangkat disediakan sendiri oleh pegawai. Bahkan beberapa organisasi atau perusahaan mensyaratkan ketersediaan internet dengan kapasitas dan kecepatan tertentu di rumah. Hal ini untuk memastikan komunikasi dapat berjalan lancar antara pegawai dan kantor. Sementara jika perusahaan menyediakan perangkat pendukung, sebaiknya tidak membebani atau mengurangi tunjangan pegawai. 
Dipahami bersama bahwa tidak semua jenis pekerjaan sesuai dilaksanakan dari rumah. Riset yang dilakukan oleh Virtual Vocation (2020)29 di Amerika Serikat, Amerika Utara dan Eropa diperoleh gambaran bahwa jenis pekerjaan yang paling banyak ditawarkan adalah pekerjaan menyangkut administrasi, teknologi informasi, desain, keuangan, pemasaran, sumberdaya manusia, manajemen proyek, dan menulis. Dan hal ini sejalan berdasarkan hasil survey terhadap ASN Pemerintah Kota Yogyakarta, bahwa jenis pekerjaan yang memungkinkan dilakukan dari rumah atau Flexible Working Arrangement adalah pekerjaan administratif dan pelayanan yang didukung teknologi informasi. Sedangkan untuk jenis pekerjaan yang tidak dapat dilakukan untuk bekerja dari rumah. Antara lain: 1) Pekerjaan yang langsung berkaitan dengan pelayanan kesehatan; 2) Pekerjaan lapangan seperti; pemadam kebakaran, petugas kebersihan, perawatan taman kota, surveyor lapangan, dan penanggulan bencana, dan lain-lain; 3) Pekerjaan yang harus melakukan pencermatan secara langsung karena mengalami kesulitan dilaksanakan secara online seperti melihat data lapangan ataupun berkaitan dengan verifikasi dokumen.

Dengan demikian, pemetaan kelayakan jenis pekerjaan yang dapat dilakukan di rumah pada masing-masing organisasi/institusi menjadi suatu keniscayaan. Berdasarkan uraian di atas, maka Pemerintah Kota Yogyakarta perlu mengambil kebijakan sebagai berikut:

\section{Revisi Peraturan Walikota Nomor 54 Tahun 2020}

Peraturan Walikota saat ini perlu direvisi karena substansinya belum komprehensif, hanya mengatur mengenai hal-hal teknis seperti pra kondisi sumber daya manusia, pra kondisi lingkungan kerja, pelaksanaan kerja yang lebih banyak berisi uraian teknis, serta protokol pelayanan internal dan eksternal kantor. Adapun revisi Peraturan Walikota ini merupakan hal yang mendesak, yang substansinya dapat meliputi penataan metode kerja, penataan jadwal kerja, penataan akses data atau dokumen kerja, serta metode pemantauan atau pengawasan dan evaluasi kinerja. Selain itu perlu diatur juga mengenai sub sistem manajemen untuk mendukung sistem kerja WFO dan WFH. Sub sistem manajemen ini antara lain manajemen sumber daya pegawai, manajemen jenis pekerjaan, manajemen konektivitas antara sistem kerja WFH dan WFO, manajemen infrastruktur pendukung sistem kerja, serta manajemen dukungan anggaran. Revisi Peraturan Walikota harus diarahkan untuk mewujudkan manajemen dan sistem kerja pegawai yang tertib dan berorientasi pada pelayanan publik yang optimal.

2. Membentuk Standar Operasional Prosedur (SOP) dan/atau Peraturan Kepala Perangkat Daerah

Selain revisi Peraturan Walikota, penting pula kepada Kepala Perangkat Daerah atau Unit Kerja di Pemerintah Kota Yogyakarta untuk menyusun standar

29 Hess, Melanie. (2020). The New Coronavirus Drives Need for Remote Work. Virtual Vocations. https://www.virtualvocations.com/blog/articles/current-events/thenew-coronavirus-drives-need-forremote-work/, 7 Desember 2020. 
operasional prosedur tata kerja Pegawai di Perangkat Daerah atau Unit Kerja masingmasing dengan berpedoman pada Peraturan Walikota yang mengatur manajemen dan sistem kerja pegawai dalam tatanan normal baru. SOP dapat lebih secara spesifik memuat klasifikasi jenis-jenis pekerjaan kedinasan sesuai bidang perangkat daerah masing-masing yang dapat diselenggarakan dengan sistem WFH dan WFO, selain itu juga dapat mengatur secara spesifik penjadwalan kerja, sistem akses data atau dokumentasi kerja kedinasan, sistem pemantauan atau pengawasan dan evaluasi kinerja oleh masing-masing organisasi perangkat daerah. SOP ini dapat dituangkan melalui Peraturan Kepala Dinas yang didalamnya mengatur protokol kesehatan pelaksanaan tugas dikantor serta pengendalian pelaksanaan SOP tata kerja Pegawai yang menyelenggarakan kedinasan dengan metode jarak jauh (WFH) melalui online.

\section{Kesimpulan}

Sistem kerja birokrasi di masa pandemi dapat menjadi momentum reformasi birokrasi. Sistem kerja birokrasi yang dihadapkan pada kondisi pandemi disesuaikan dengan merumuskan strategi pelaksanaan transformasi sistem kerja birokrasi. Kondisi Pandemi Covid-19 telah mengubah paradigma sistem bekerja ASN menjadi lebih efektif dan efisien. Kondisi ini dapat dimanfaatkan untuk mengoptimalkan pelayanan publik dengan tetap memprioritaskan kesehatan dan keselamatan pegawai di lingkungan Pemerintah Kota Yogyakarta. Perwal Nomor 54 Tahun 2020 tentang Pedoman Tata Kerja Pegawai dalam Tatanan Normal Baru di Pemerintah Kota Yogyakarta mengadopsi 2 (dua) sistem kerja (model blended system), yaitu Work From Office (WFO) sebagai sistem kerja yang dilaksanakan di kantor dan Work From Home (WFH), sebagai sistem kerja dari rumah pada hari tertentu atau untuk periode sementara guna meminimalisir risiko pada kesehatan dan keselamatan pegawai.

Guna meraih peluang dalam momentum reformasi birokrasi di masa pandemi, maka penelitian ini merumuskan kerangka alternatif desain sistem kerja WFO yang dikolaborasi dengan WFH sebagai satu kesatuan sistem kerja di Pemerintahan Kota Yogyakarta, yang meliputi penataan metode kerja, penataan jadwal kerja, penataan akses data atau dokumen kerja, serta metode pemantauan atau pengawasan dan evaluasi kinerja. Untuk mewujudkan sistem kerja kolaboratif dengan sistem WFO dan WFH di Pemerintah Kota Yogyakarta, maka perlu didukung beberapa sub sistem manajemen. Sub sistem manajemen ini antara lain manajemen sumber daya pegawai, manajemen jenis pekerjaan, manajemen konektivitas antara sistem kerja WFH dan WFO, manajemen infrastruktur pendukung sistem kerja, serta manajemen dukungan anggaran

Penelitian ini merekomendasikan agar Pemerintah Kota Yogyakarta mengambil kebijakan melalui revisi Perwal No. 54 Tahun 2020 tentang Pedoman Tata Kerja Pegawai dalam Tatanan Normal Baru di Pemerintah Kota Yogyakarta untuk melengkapi kekurangan/kekosongan pengaturan mengenai manajemen kinerja pegawai dan sistem kerja birokrasi di Pemerintah Kota Yogyakarta. Sekaligus apabila 
diperlukan juga membentuk SOP sebagai dasar dan pedoman operasional sistem kerja pada tiap instansi perangkat daerah di Kota Yogyakarta.

\section{Daftar Pustaka}

Amrynudin, A.D.K. dan Katharina, R. (2020). Birokrasi dan Kebijakan Percepatan Penanganan Covid-19", Info Singkat Pusat Penelitian Badan Keahlian DPR RI, 12(9), 25-30.

Attamimi, H.. (2018). Perbedaan antara Peraturan Perundang-undangan dan Peraturan Kebijaksanaan, Suatu Tantangan Bagi Peran POLRI Dewasa ini dan Menghadapi Pembangunan Jangka Panjang Kedua, sebagaimana dikutip kembali oleh SF Marbun. (2018). Hukum Administrasi Negara 1, Yogyakarta: FH UII Press, hal. 256257

Cahyono, E. (2020). Asisten Deputi Hubungan Masyarakat Kementerian Sekretaris Negara, The New Normal dan Akselerasi reformasi Birokrasi, dalam https://setneg.go.id/baca/index/the_new_normal_dan_akselerasi_reformasi_bi rokrasi (di akses 20 Oktober 2020)

Fadillah, P. (2009). Senjakala Good Governance. Malang: Averroes Press.

Gardner, James A.. (1961). The Sociological Jurisprudence of Roscoe Pound (Part I), Villanova Law Review, 7(1).

Hess, Melanie. (2020). The New Coronavirus Drives Need for Remote Work. Virtual Vocations. $\quad$ https://www.virtualvocations.com/blog/articles/currentevents/thenew-coronavirus-drives-need-for-remote-work/, 7 Desember 2020.

Husaini, Abdullah. (2017). Peranan Manajemen Sumber Daya Manusia dalam Organisasi. Jurnal Warta (50).

Irawati, E.. (2020). Aparatur Sipil Negara di Masa Pandemi: Tinjauan Kebijakan Normal Baru di Provinsi Jawa Tengah. Prosiding The $2^{\text {nd }}$ Seminar on Population, Family and Human Resources, hal. 99-105.

Laporan Penelitian Anagata Sasmitaloka Consulting (ANSAC), Yogyakarta, 2020.

M. Kadarisman. (2013). Manajemen Pengembangan Sumber Daya Manusia. Jakarta:Rajawali Press.

Marbun, S.F. (2018). Hukum Administrasi Negara 1, Yogyakarta: FH UII Press.

Mungkasa, O. (2020). Bekerja dari Rumah (Working from Home/WFH): Menuju Tatanan Baru Era Pandemi COVID 19. The Indonesian Journal of Development Planning, 4(2).

Natalisa, D. (2020). Deputi bidang Pelayanan Publik Kementerian PANRB, Tatanan Normal Baru Butuh Birokrasi Pelayanan yang Sederhana, dalam 
https://www.menpan.go.id/site/berita-terkini/tatanan-normal-baru-butuhbirokrasi-pelayanan-yang-sederhana (diakses 20 Oktober 2020)

Ridwan. (2020). Hukum Administrasi Negara, Depok: Rajawali Pers.

Sahban, H. (2018). Meningkatkan Kinerja Pelayanan Birokrasi Pemerintahan Melalui Penguasaan Teknologi Informasi. Jurnal Manajemen Bisnis, 5(2).

Sawir, M. (2020). Tinjauan Mengenai Fungsi Birokrasi Pemerintahan Di Indonesia, dalam https://core.ac.uk/download/pdf/229023096.pdf , hlm. 214 (diakses 21 September 2020)

Taufik dan Warsono, H. 2020. Birokrasi Baru untuk New Normal: Tinjauan Model Perubahan Birokrasi dalam Pelayanan Publik di Era Covid-19. Dialogue Jurnal Ilmu Administrasi Publik. 2(1), 1-18

Yuningsih, T. (2019). Kajian Birokrasi. Semarang: Departemen Administrasi Publik Press FISIP-UDIP.

\section{Peraturan Perundang-undangan dan Keputusan TUN}

Keputusan Presiden Nomor 11 Tahun 2020 berbunyi "bahwa penyebaran Corona Virus Disease 2019 (COVID-19) yang bersifat luar biasa dengan ditandai jumlah kasus dan/atau jumlah kematian telah meningkat dan meluas lintas wilayah dan lintas negara yang berdampak pada aspek politik, ekonomi, sosial, budaya, pertahanan dan keamanan, serta kesejahteraan masyarakat di Indonesia".

Keputusan Presiden Nomor 12 Tahun 2020 berbunyi "bahwa bencana nonalam yang disebabkan oleh penyebaran Corona Virus Disease 2019 (COVID-19) telah berdampak meningkatnya jumlah korban dan kerugian harta benda, meluasnya cakupan wilayah yang terkena bencana, serta menimbulkan implikasi pada aspek sosial ekonomi yang luas di Indonesia; bahwa World Health Organization (WHO) telah menyatakan COVID-19 sebagai Global Pandemic tanggal 11 Maret 2020."

Peraturan Presiden Republik Indonesia Nomor 81 Tahun 2010 tentang Grand Design Reformasi Birokrasi Nasional.

Peraturan Walikota Yogyakarta Nomor 54 Tahun 2020 tentang Pedoman Tata Kerja Pegawai Dalam Tatanan Normal Baru Di Pemerintah Kota Yogyakarta. 